\title{
'You have to keep your head on your shoulders': A systems psychodynamic perspective on women leaders
}

\begin{tabular}{|c|c|}
\hline \multicolumn{2}{|c|}{ 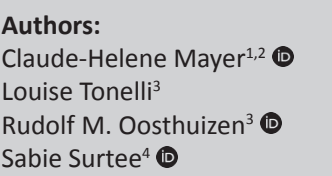 } \\
\hline \multicolumn{2}{|c|}{$\begin{array}{l}\text { Affiliations: } \\
\text { }{ }^{1} \text { Department of } \\
\text { Management, Rhodes } \\
\text { University, South Africa }\end{array}$} \\
\hline \multicolumn{2}{|c|}{$\begin{array}{l}{ }^{2} \text { Institut für Therapeutische } \\
\text { Kommunikation und } \\
\text { Sprachgebrauch, Europa- } \\
\text { Universität Viadrina, } \\
\text { Frankfurt (Oder) }\end{array}$} \\
\hline \multicolumn{2}{|c|}{$\begin{array}{l}{ }^{3} \text { Department of Industrial } \\
\text { and Organisational } \\
\text { Psychology, University of } \\
\text { South Africa, South Africa }\end{array}$} \\
\hline \multicolumn{2}{|c|}{$\begin{array}{l}{ }^{4} \text { Higher Education Resource } \\
\text { Services South Africa, Cape } \\
\text { Town, South Africa. }\end{array}$} \\
\hline \multicolumn{2}{|c|}{$\begin{array}{l}\text { Corresponding author: } \\
\text { Rudolf Oosthuizen, } \\
\text { oosthrm@unisa.ac.za }\end{array}$} \\
\hline \multicolumn{2}{|c|}{$\begin{array}{l}\text { Dates: } \\
\text { Received: } 29 \text { Nov. } 2016 \\
\text { Accepted: } 06 \text { Nov. } 2017 \\
\text { Published: } 19 \text { Mar. } 2018\end{array}$} \\
\hline \multicolumn{2}{|c|}{$\begin{array}{l}\text { How to cite this article: } \\
\text { Mayer, C-H., Tonelli, L., } \\
\text { Oosthuizen, R.M. \& Surtee, S. } \\
\text { (2018). 'You have to keep } \\
\text { your head on your } \\
\text { shoulders': A systems } \\
\text { psychodynamic perspective } \\
\text { on women leaders, SA } \\
\text { Journal of Industrial } \\
\text { Psychology/SA Tydskrif vir } \\
\text { Bedryfsielkunde, 44(0), } \\
\text { a1424. https://doi.org/ } \\
\text { 10.4102/sajip.v44i0.1424 }\end{array}$} \\
\hline \multicolumn{2}{|l|}{ Read online: } \\
\hline 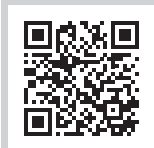 & $\begin{array}{l}\text { Scan this QR } \\
\text { code with your } \\
\text { smart phone or } \\
\text { mobile device } \\
\text { to read online. }\end{array}$ \\
\hline
\end{tabular}

Background: Women leaders within Higher Education Institutions (HEIs) in South Africa have increased in numbers over the past years and they have changed the dynamics in these institutions. Yet, it is a subject that has hardly been explored from the perspective of women leaders.

Aim: The aim of this study is to explore the experiences of women leaders in HEIs from a systems psychodynamic perspective using the conflict, identity, boundaries, authority, roles, task (CIBART) model, a well-researched model to analyse systems psychodynamics and to gain a deeper understanding of (un)conscious dynamics within organisations.

Methods: This qualitative study is based on Dilthey's modern hermeneutics. Interviews were conducted with 23 women leaders from the Higher Education Resource Services South Africa, network across 8 HEIs. Observations were conducted in one organisation to support the data analysis and interpretation. Data were analysed through content analysis.

Findings: Findings show that women leaders re-evaluate and reconstruct themselves constantly within organisations. This continuous re-evaluation and reconstruction become visible through the constructs of the CIBART model. The findings reveal deeper insights into systems psychodynamics, which considers anxiety within the system where women leaders seem to contain such anxiety by mobilising specific defence mechanisms. Certain diversity markers, such as race, gender, mother tongue, position within the organisation and generational belonging play a role in creating the dynamics. Women leaders' experience of de-authorisation and role confusion impacts significantly on women leadership and their action towards ownership.

Practical implications: The study provides new, valuable and context-specific insights into women leadership seen through the lens of the CIBART model, highlighting unconscious dynamics that need practical attention in the HEIs to empower women leaders for genderspecific leadership training.

Originality or value: Findings provide a foundation for future research on women leaders and applied solutions to empower women leaders, whilst reducing anxiety within the system. The study provides complex insights, which should create increasing awareness in women leaders towards being containers of anxiety and creating new ways of empowered women leadership.

\section{Introduction}

Over the past few years, research from a systems psychodynamic perspective in work and organisational settings has increased (Eloquin, 2016; Steyn \& Cilliers, 2016). From a systemic thinking perspective, systems are defined by their boundaries, separating them from their environment and other systems. If individuals are understood in the context of systems and systemic dynamics, new information are gained to improve the understanding of the conscious and unconscious dynamics impacting on cognitive, symbolic, affective and behavioural processes within such systems (Koortzen \& Cilliers, 2002).

A systems psychodynamic perspective enables an understanding of the dynamics between individuals and system elements, such as ineffective interventions (Koortzen \& Cilliers, 2002), conflict (Mayer, 2011) or decreased health and well-being (Mayer \& Surtee, 2015), which may contribute to an increased understanding of (un-)conscious dynamics within the individual and

Copyright: @ 2018. The Authors. Licensee: AOSIS. This work is licensed under the Creative Commons Attribution License. 
the system. Structural aspects influencing organisations are then defined as open systems, which may be explored (Greyvenstein \& Cilliers, 2012). Psychoanalysis is an epistemology within systems psychodynamics that considers the role of unconscious processes within organisations. By focusing on both the system and psychological aspects within organisations, (un-)conscious dynamics of subsystems emerge and relate to and mirror one another (Naik, 2014), thereby providing new, in-depth information of the dynamics beneath the surface (Clarke \& Hoggett, 2009). Unconscious processes that influence health, well-being and (psychological) wellness within the organisation (Henning, 2009; Rothmann \& Cilliers, 2007) and organisational change (Golom, 2017) should therefore be taken into account.

Cytrynbaum and Noumair (2004) discuss the BART model with its constructs of boundary (B), authority (A), role (R) and task $(\mathrm{T})$ within the Tavistock conference framework. Cilliers and Koortzen (2005) added to the constructs of the BART model with two more constructs, namely conflict (C) and identity (I), which explore the aspects of conflict and identity from a systems psychodynamic perspective as these become evident in the individual, group and organisation. Over the past decade, the conflict, identity, boundaries, authority, roles, task (CIBART) model has been researched extensively from different perspectives, such as conflict in teams and groups, leadership, followership and psychological wellness (De Klerk \& Africa, 2012; Sanchen, 2009; Shongwe, 2014; Struwig, Cilliers, Africa \& Greyvenstein, 2012) and relates the aspects of CIBART to underlying dynamics, such as uncertainty and anxiety within systems (Shongwe, 2014).

\section{The context: Women leadership in Higher Education Institutions}

Women leadership has been researched extensively within Higher Education Institutions (HEIs) and has been explored as a positive or contingent experience ( $\mathrm{O}^{\prime}$ Conner, Carvalho \& White, 2014). Within a South African perspective, leadership in HEIs has been studied (Kinnear, 2014; Mayer \& Barnard, 2015; Mayer, Surtee \& Barnard, 2015; Mayer, Surtee \& May, 2015; Mostert, 2009), highlighting gender inequalities (Ragadu; 2008; Surajlall, 2012); however, underlying dynamics seem to stay under-researched from a systems psychodynamic perspective.

Higher Education Institutions, as open, non-discriminatory institutions in South Africa (South African Government, 1997), face many challenges regarding the transformation of South African society. In this context, research has particularly investigated gender and race in leadership in HEI contexts (Littrell \& Nkomo, 2005; Mayer \& Barnard, 2015; Morley, 2013) and has shown that gender roles, concepts and dynamics (Du Plessis \& Barkhuizen, 2012; Gouws, 2008; Mayer \& Barnard, 2015), as well as workplace conflict (Mabokela, Kaluke \& Mawila, 2004; Mayer et al., 2015; Mayer, Surtee \& Mahadevan, 2018; Ugwu, Orjiakor, Enwereuzor, Onyedibe \& Ugwu, 2016), need to be addressed.
Research further indicates that although the number of women leaders has increased globally and within South Africa (International Labour Organization, 2010), gender inequalities (Kinnear, 2014; Mostert 2009; Surtee \& Hall, 2009) remain, whilst the demand for gender-sensitive leadership training increases (Boyd, 2016). Thus, a systems psychodynamic perspective might provide insights into the well-being of women leaders in organisations (Alexander, LaRosa, Bader, Garfield \& Alexander, 2014; Baxter 2012; Coovadia, Jewkes, Barron, Sanders \& McIntyre 2009), particularly because increasing numbers of young, highly educated women enter the (previously) male-dominated workspaces of HEIs and have to deal with stress and dysfunctional coping behaviour (Love, Hagberg \& Dellve, 2011).

\section{Purpose, aim and contribution}

This study's purpose is to explore the experience of women leaders in HEIs from a systems psychodynamic perspective by using the CIBART model as a reference model of analysis. The aim is to identify conscious and unconscious dynamics in the selected organisational setting of HEIs, in South Africa, to improve the understanding of women leaders and their struggles and impact on the organisational sphere (Khoury \& McNally, 2016). By using the systems psychodynamic perspective, new insights are generated that could lead a better understanding of the dynamics pertaining women leadership within HEIs (Mayer \& Van Zyl, 2013).

The contribution of this study is therefore to present findings on women leaders in HEIs from a system dynamic perspective, based on the CIBART model, to understand more deeply how systems psychodynamic aspects impact on women leaders within this context by also taking into account the unconscious dynamics between the women leaders and the organisation.

\section{Systems psychodynamics and the CIBART model}

Systems psychodynamic theories provide an organisational approach to the understanding and explaining of systemic structures (Steyn \& Cilliers, 2016). According to these theories, systemic structures are related to deeply entrenched, unspoken and unconscious individual, social and organisational anxiety (Armstrong, 2005). Anxiety is viewed as a major force in open systems and is expected to cause psychological pain, which the system then defends itself against (Sievers, 2009).

Defence mechanisms might vary in reactions, such as splitting, projection, projective identification and idealisation (Blackman, 2004). Only if the system addresses the anxiety and integrates positive and negative aspects of itself can it cater for objective human relations to finally contain the anxiety (Cytrybaum \& Noumair, 2004). If individuals are unable to deal with anxiety in organisations, it is blocked out of the conscious mind, which largely shapes the nature of the system, its culture, structure and leadership. Unconscious fear can lead to the regression in individuals and groups, an 
increase in conflicts from a defensive position and deteriorating relationships as a social defence mechanism to contain anxiety (Van Tonder, 2012).

Steyn and Cilliers (2016) provide an overview of five possible group behaviour reactions based on a broad literature review about managing anxiety in the system, such as: (1) relating to an imaginative caring parental figure; (2) pairing up of individuals and/or powerful objects to manage the pain of anxiety; (3) fight or flight against an (imaginative) enemy; (4) one-ness or we-ness to create individuality, whilst joining in a force to experience health and (5) me-ness, in the way of denouncing or detaching from the group affiliation to cope with emotional demands.

A construct often used in systems psychodynamics to explore and explain employee's experiences of organisational phenomena is the CIBART model (Cilliers \& Koortzen, 2005; Steyn \& Cilliers, 2006), as explained in the following sections.

\section{Conflict}

Conflict serves as a driving force in organisations, for example, in team performance, creativity, innovation and coping with organisational change and transformation (Cilliers \& Koortzen, 2005; Mayer, 2008). It derives from experiences of (unconscious) anxiety, exposure to positive and negative aspects of the organisation (Cilliers \& Koortzen, 2005; Steyn \& Cilliers, 2016) and the influences of leadership, role formation, identity boundaries and authority, which manifest as unconscious patterns of ego defences, such as fight or flight responses (Koortzen \& Oosthuizen, 2012). As a result of the unconscious need to feel secure (Bion, 1961), the individual or group then tries to alleviate anxiety, for example, by pairing with powerful others and splitting from others to build smaller, seemingly safer, systems (Koortzen \& Oosthuizen, 2012), as explained above.

\section{Identity}

Identity is the fingerprint of the organisation and includes characteristics that make the team, their task and their culture different and unique from others (Cilliers \& Koortzen, 2005). Team identity is greatly influenced by the personality and the style of the leader. A lack of identification with the systems' values and performance leads to feelings of not belonging and a sense of hopelessness and helplessness. In predominantly masculine environments, women leaders may resort to defensive patterns of behaviour and behave as men to blend in, whilst experiencing work-family conflict as well (Naik, 2014). This inevitably affects women's self-identity and selfauthority in terms of their own sense of potential, ambition, achievement and self-worth (Naik, 2014). Another study pointed out that diversity markers, such as generational belonging, age, gender, status, language and race, which contribute to identity creation, impact on the system psychodynamics within a group relation event and need to be considered in organisations as well (Cilliers \& Smit, 2006).

\section{Boundaries}

Boundaries determine what belongs to the system and what does not (Cilliers \& Koortzen, 2005; Geldenhuys, 2012). The psychosocial basis of group structures provides for sensegiving processes that are dynamic and it is continuously reforming and redefining people, groups and organisations, their boundaries and space around and in-between them for protection and containment. Boundaries provide the structure to contain anxiety in the system and a lack of boundaries creates non-relatedness, decreased relationships and the feeling of being lost. Boundaries create meaningfulness, safety, control and a way of classifying and categorising the world (Struwig \& Cilliers, 2012).

\section{Authority}

Beck and Visholm (2014) describe authority as the right to make binding decisions for self and others, the duty to obey legitimised authority, whilst distinguishing between rolebased and persona-based authority. Legitimised role-based authority is usually passed down from the organisation to leaders as definite boundaries and limits. Cilliers and Koortzen (2005) define this as formal authority, where an individual has the recognised competence as an expert, leader or achiever. Informal authority (Cilliers \& Koortzen, 2005) or person-based authority (Beck \& Visholm, 2014) is based on sympathy of peers and employees given to colleagues or leaders and can be withheld at any moment. Authority is a dynamic concept that is negotiable and renegotiated between the leader and the group (Cilliers \& Koortzen, 2005).

\section{Role}

Authority is tied to positions or roles (Beck \& Visholm, 2014). Individuals take up roles at intersections between the individual, their identity and the organisation, with its tasks and structures (Cilliers \& Koortzen, 2005). The normative role is guided by the task, duty and responsibility and the objective job content. According to Cytrynbaum and Noumair (2004), the role is defined by normative (explicit and conscious content), existential (past experiences, personality, values and preferences) and phenomenal tasks (projections from others on the employee), and incongruences between these roles create anxiety and poor performance in individuals, groups and organisations (Cilliers \& Koortzen, 2005).

\section{Task}

Task refers to the job content and performance criteria, in other words, that which keeps the employees employed. The system pursues both, conscious and unconscious tasks, impacting on the efficiency and the degree of anxiety experienced within the system. Task is the basic component of work (Cilliers \& Koortzen, 2005) and is split into primary and secondary task functioning and off-task and anti-task behaviour (Cytrybaum \& Noumair, 2004). A primary task is the task that constitutes the raison d'être of the system, which is the dynamic force to keep individuals in business 
and/or employed, whilst the secondary tasks support the primary (Cilliers \& Koortzen, 2005).

\section{Research methodology}

The hermeneutic phenomenological perspective, which is orientated towards lived experiences and interpreting life texts, was expected to yield rich and detailed descriptions of women leaders in South African HEIs (Creswell, 2013; Fossey, Harvey, McDermott \& Davidson, 2002; Ramgoolam, 2005; Zambas, Smythe \& Koziol-McLain, 2016). The concept of Dilthey's (2002) modern hermeneutics was used to create 'verstehen' (understanding) from an in-depth perspective of the CIBART model. To construct, analyse and interpret the data, researchers used a self-reflective attitude, as described by Ratner (2002), whilst the 'privileged position of the researcher vis-à-vis the researched' is strongly emphasised (Raheim et al., 2016).

\section{Sample}

During this research, purposive and snowball sampling was used. Women leaders were invited to participate in this research project through their membership with HERS-SA (Higher Education Resource Services South Africa). Purposive sampling is a form of:

non-probability sampling in which decisions concerning the individuals to be included in the sample are taken by the researcher, based upon a variety of criteria which may include specialist knowledge of the research issue, or capacity and willingness to participate in the research. (Oliver, 2006, pp. 245-246)

HERS-SA is a non-profit organisation in South Africa, which offers professional and leadership development for women in HEIs. In the case of this study, 29 women, out of 900 members, agreed to participate in qualitative interviews, based on their HEI leadership positions, their specialised knowledge as women leaders and their willingness and interest to participate. Participants were located at eight different HEIs in South Africa.

\section{Data collection}

Data were collected through semi-structured interviews, which took 30-60 min to conduct. Two researchers conducted the interviews and established themselves within the field as 'external, independent researchers' (Babbie \& Mouton, 2006, p. 520; Mayer \& Boness, 2011), whilst establishing contact with HERS members and building trustful relationships. Interviews were conducted either via Skype or through face-to-face interactions. The interview questions referred to gender, identity and conflict and were recorded and transcribed verbatim. The observations of the researchers were captured in field notes.

\section{Data analysis and interpretation}

Interview data were analysed through the five-step process of content analysis: step 1 - familiarisation and immersion; step 2 - inducing themes; step 3 - coding; step 4 - elaboration; and step 5 - interpretation and checking (Krane, Karlsson, Ness \& Binder, 2016; Terre Blanche, Durrheim \& Kelly, 2006, pp. 322-326). Content analysis was used to identify key issues in the data on women leaders, thereby guiding the process of analysis, which was fundamentally influenced by the subjective process between the researcher and the texts (Mayer, 2011). The analysis included the identification of themes, categories and codes, and observation notes were used for the interpretation of interview data, which contributed to a deeper understanding, analysis and interpretation of the data (Yin, 2009).

Content analysis either uses predefined categories or inductive-analytical procedures (Streib, 2005). This study used predefined categories (as provided by the CIBART model) and inductive-analytical categories, which are developed through familiarisation with the texts. Yin (2009) emphasises that content analysis is conducted through interand intra-individual verification processes aimed at adhering to particular processes of analysis and regulations, thereby verifying the findings. In the case of this study, the main researcher used intra-individual verification processes (repeated self-reflections and questioning of interpretations at different points in time), on the one hand, and inter-individual verification processes (researchers' groups discussions and interpretations of data and findings at different points in time throughout the process of data collection and analysis), in the context of the research group, on the other hand. The researchers' involvement and the hermeneutical interpretation and reconstruction of the texts is thereby understood in the context of hermeneutical interpretation and viewed as a systematic and replicable technique to create categories from the database (Mayring, 2014).

\section{Qualitative research criteria}

Qualitative research criteria included the definitions of the following: worthy topic, rich rigor, sincerity, credibility, resonance, the significant contribution, ethics and the meaningful coherence (Tracy, 2010). Data quality was ensured through informed consent, anonymity, rigorous analysis and constant comparison of the data and of the research topic throughout the analysis (Charmaz, 2011). Participants voluntarily participated in the study. Intersubjective validation processes were conducted amongst the researchers throughout the research study (Englander, 2016; Yin, 2009).

\section{Limitations}

As with any study, this study had to deal with certain limitations. Methodologically, it is limited to a qualitative hermeneutical research paradigm and to a relatively small set of HERS-related participants. It is limited to the analysis of the data set in relation to the CIBART model and the aim of the article, which is to understand women leaders' perspectives based on the systems psychodynamic perspective. The study does not proclaim generalisations, but provides an orientation for future research and practice regarding women leaders, from the defined perspective. 


\section{Findings}

Women leaders in South African HEIs experience underlying dynamics at work, as described in the CIBART model. Overt and covert issues are narrated and analysed through the systems psychodynamic perspective. Direct quotes will be included according to selected, most recurrent and/or most extraordinary themes.

\section{Conflict}

Women leaders experience conflict on various levels within their HEIs. These will be identified and discussed in the following sections.

\section{Individual conflict}

Women leaders experience conflict regarding diversity issues (language, race and generational), differences of individual priorities and interests (clashing values, particularly) and 'inappropriate' behaviour (particularly aggression and defensiveness) (see Table 1). Eleven women feel that conflict arises in terms of diversity, experienced individually. Major conflict is based on conflicts between generations, differences in languages (the use of mother tongue to exclude others) and discrimination because of racial belonging. Interviewee ${ }^{1}$ W10 highlights that she experiences conflict because of the use of mother tongue to communicate at work, which creates a feeling of anxiety of exclusion:

'A young lady was giving feedback very quickly, in an African language, and I couldn't understand.'

So, I came out of my office and said:

'Please people, I'm feeling excluded here and please just tell me what's going on'.

'Several times during director training, you hear white people speaking Afrikaans, and this excludes others.'

Further, 11 statements refer to conflicts based on individual interests and priorities at work, such as personal values and interests, as well as work-related opinions and their (open) expression in the context of colleagues and students. W7 highlights:

'It can be on a level where they have basic standpoints, and differences in their points of view and how things are done. So, conflict is anywhere where people's views would clash when trying to meet a goal - you might agree on the goal, but you might not agree on how to get there.'

Finally, four statements relate to conflict based on inappropriate behaviour, which is either referred to as aggressive or defensive. However, women do not necessarily identify the problem as inappropriate behaviour displayed by others (B12, W14, W27), but rather as their inability to access or express their own emotions in an 'appropriate way'.

1.Interview numbers are defined as follows: $I=$ Indian women leader, $C=$ coloured woman leader, $W$ = white women leader, $B=$ black women leader. For example: $110=$ Ine $110=$ Interview number 10 , Indian woman leader or $W 12=$ Interview number 12 white woman leader. The interviewees (participants) indicated coloured to identify
race in the interviews, therefore coloured will be referred to throughout the article.

\section{Group conflict}

Women leaders ascribe behaviour to certain groups that is experienced as conflictual, leading to latent or manifest conflicts in HEIs (see Table 2). Sixteen women leaders experience conflict based on group perceptions. Several women refer to conflict based on women leadership attitudes and behaviour, or gendered leadership concepts. For example, B12 highlights:

'I want to appeal to women or those who get appointed to senior positions. Please try and avoid acting like a man.'

According to this leader, manly behaviour in women creates conflict.

Other women leaders highlight that, at a group level, 'women care too much', which leads to conflict and a blurring of boundaries, because as B12 stated:

'... women tend to be taken for granted; because of our caring and soft nature, people tend to relate that to weakness'.

Therefore, women are also advised not to act 'too much like women'.

Other sources of conflict occur around emotions. B21 feels that 'we, as women are too emotional', whilst other women

TABLE 1: Individual level conflict of women leaders.

\begin{tabular}{llll}
\hline Conflict level & Theme & Interview numbers & Total number \\
\hline Individual level & $\begin{array}{l}\text { Diversity issues } \\
\text { (generations, } \\
\text { language and race) }\end{array}$ & C: 9,28 & 11 \\
& & A: 12,21 & \\
& W: $6,7,10,15,16$ & \\
& I: 9,18 \\
& Interests and & C: $8,13,23,19$ & 11 \\
& & A: $12,29,21$ & \\
& & W: $3,7,27$ & \\
& Inappropriate (values) & C: 23 & \\
& behaviour & B: 12 & \\
\hline (aggression, defence) & W: 14,27 & 26 \\
\hline $\begin{array}{l}\text { Total individual } \\
\text { conflict level }\end{array}$ & - & - & \\
\hline
\end{tabular}

TABLE 2: Conflict on group level of women leaders.

\begin{tabular}{|c|c|c|c|}
\hline Conflict level & Theme & Interview numbers & Total number \\
\hline \multirow[t]{16}{*}{ Group level } & \multirow{4}{*}{$\begin{array}{l}\text { Women leadership } \\
\text { attitude and behaviour }\end{array}$} & $W: 3,6,7,10,11,15,27$ & \multirow[t]{4}{*}{16} \\
\hline & & I: 18 & \\
\hline & & A: $12,21,22,29$ & \\
\hline & & C: $13,19,23,28$ & \\
\hline & \multirow{3}{*}{$\begin{array}{l}\text { Conflict between } \\
\text { subgroups or divisions }\end{array}$} & C: 9, 28; A: 21 & \multirow[t]{3}{*}{9} \\
\hline & & $W: 2,7,15,16,6$ & \\
\hline & & I: 9 & \\
\hline & \multirow[t]{3}{*}{ Management style } & C: $28,23,13$ & \multirow[t]{3}{*}{5} \\
\hline & & W: 14 & \\
\hline & & I: 9 & \\
\hline & \multirow[t]{2}{*}{ Office space } & C: 8,13 & \multirow[t]{2}{*}{4} \\
\hline & & $W: 10,15$ & \\
\hline & \multirow{2}{*}{$\begin{array}{l}\text { Work attitude and } \\
\text { commitment }\end{array}$} & C: 19 & \multirow[t]{2}{*}{2} \\
\hline & & A: 12 & \\
\hline & \multirow[t]{2}{*}{ Salary } & C: 28 & \multirow[t]{2}{*}{2} \\
\hline & & W: 7 & \\
\hline $\begin{array}{l}\text { Total group } \\
\text { conflict level }\end{array}$ & - & - & 48 \\
\hline
\end{tabular}


$(\mathrm{C} 19, \mathrm{C} 23, \mathrm{I18})$ feel that it creates conflict when women do not display their emotions, for example, 'do not show anger', because they have learned to 'not anger people'. Women leaders feel that their emotional way of dealing with situations creates conflict, rather than decreasing it (B21, W6, W10, and W11). W11 highlights:

'I find that women bring a lot more emotion to the conflict situation, including myself, and sometimes you get clouded with emotion. I have found that when we had a man in our midst, it tended to sort of tone down the hysteria at times.'

W11 highlights that leadership needs 'emotional maturity' and M8 points out that she has a 'great capacity of passion and generosity'. Additionally, conflict arises based on membership of subgroups and/or divisions at work (belonging to a particular discipline, division or group, with a specific world view being ascribed to certain categories (e.g. 'the realist', W7) or when there is conflict between management and academics in HEIs (e.g. W29). Group conflict within HEIs develops based on ineffective or inadequate management styles. W14 reflects on her previous leadership style, which created conflict and anxiety in others. Four women mention that conflict is based on arguments, negotiation and 'conflict about office space' (C13), whilst one woman highlights that conflict 'is about territory' (C8). Finally, two individuals each mention conflict because of differences in work attitude and commitment to work (C19, B12). Conflict is also about people who have/earn more and the people who have/ earn less (C28, W7).

\section{Social and organisational conflict}

Conflicts at work are created in the in-between space of spillover effects between society, the organisation or group and the individual (see Table 3). Twelve women experienced spill-over conflict because of societal enculturation in terms of gender. Conflict arises when women behave differently to societal gender role expectations or they are treated differently to men because of (societal) gender stereotypes. The clash of gender-based expectations and prescriptions and the individual behaviour or attitude of women leaders leads to conflict. W10 emphasises:

\begin{tabular}{|c|c|c|c|}
\hline Conflict level & Theme & Interview numbers & Total number \\
\hline \multirow{12}{*}{$\begin{array}{l}\text { Societal and organisational } \\
\text { level }\end{array}$} & \multirow{4}{*}{$\begin{array}{l}\text { Gender } \\
\text { enculturalisation }\end{array}$} & C: $8,13,19,23,28$ & \multirow[t]{4}{*}{12} \\
\hline & & A: 21,29 & \\
\hline & & W: $3,15,16,27$ & \\
\hline & & I: 9 & \\
\hline & \multirow{4}{*}{$\begin{array}{l}\text { Socio-historical } \\
\text { racial issues }\end{array}$} & C: $8,19,23,28,13$ & \multirow[t]{4}{*}{11} \\
\hline & & A: 21,22 & \\
\hline & & I: $9,17,18$ & \\
\hline & & $W: 0$ & \\
\hline & \multirow{4}{*}{$\begin{array}{l}\text { Change and its } \\
\text { (political) } \\
\text { management }\end{array}$} & C: 8,28 & \multirow[t]{4}{*}{8} \\
\hline & & A:18 & \\
\hline & & $W: 7,9,10,11$ & \\
\hline & & I: 9 & \\
\hline $\begin{array}{l}\text { Total societal organisational } \\
\text { conflict level }\end{array}$ & - & - & 31 \\
\hline
\end{tabular}

'I always think that females, and it's a stereotype, a generalisation, that they have a far worse track record than their male counterpart.'

W3 refers to how enculturation has impacted on her conflict experience and management:

'My way of managing conflict is related to my gender, because of the way I've been taught to deal with conflict, because I'm a woman. That's the kind of behaviour that's displayed towards me because I am a woman - so it would be more towards finding some compromise, and not hurting.'

Further, 11 women (coloured women, black women and Indian women) mentioned that racial issues, originally based in the sociocultural history of the country, lead to racial conflict at work. B21 emphasises:

'As a black woman working in this kind of environment, when I started, I found it to be quite a hostile environment - you actually need to win people over and when you get to that point, you actually feel you've made it. When you move to another department, this process starts again and you are always looked at with suspicion, as to whether or not you are worth what they are worth.

These women mention that, often, race and gender are combined intersections, which lead to conflicts, as C19 stipulated:

'I look at my white colleagues - white female colleagues and I see that they deal with gender issues as well. When we discuss things, I can hear they deal with gender issues. But for me, often it's not just gender that comes into play, it's also my skin colour. It's not always so; sometimes it's only gender. There are times though, when it is both.'

Finally, eight women point out that structural changes towards creating a more diverse society and organisation lead to conflict, especially relating to Affirmative Action and Black Economic Empowerment practices. I9 refers to the intersections of race and gender and highlights the difficulties of managing (political) change and change towards diversity and inclusion within the organisation.

\section{Identity}

Women leaders (36 statements) enjoy talking about their identity, about how they define themselves and who they are (see Tables 4 and 5). They define themselves in terms of their self-worth and potential (10 statements); a clear definition of who they are (9 statements); their self-exploration of their changing and dynamic identity in the past, present and future ( 7 statements); their self-consciousness ( 5 statements); and their professional career identity ( 5 statements).

TABLE 4: Identity of women leaders.

\begin{tabular}{lll}
\hline Identity:Theme & Interview numbers & Total number \\
\hline Self-worth/potential & $3 \mathrm{~W}, 2 \mathrm{C}, 3 \mathrm{I}, 2 \mathrm{~A}$ & 10 \\
Self-definition & $5 \mathrm{~W}, 2 \mathrm{C}, 1 \mathrm{~A}, 1$ Int (9) & 9 \\
Self-exploration of dynamic identity & $3 \mathrm{~W}, 2 \mathrm{C}, 1 \mathrm{~A}, 1 \mathrm{Int}(6)$ & 7 \\
Self-awareness & $3 \mathrm{~W}, 1 \mathrm{~A}, 1 \mathrm{Int}(5)$ & 5 \\
Professional career identity & $2 \mathrm{~W}, 1 \mathrm{C}, 1 \mathrm{I}$ (4) & 5 \\
\hline Total identity statements & - & 35 \\
\hline
\end{tabular}


TABLE 5: Positive self-descriptions of women leaders.

\begin{tabular}{|c|c|c|c|}
\hline Identity & Theme & Interview number & Identity \\
\hline \multirow[t]{4}{*}{ Self-descriptions } & $\begin{array}{l}\text { Excitement and positive life } \\
\text { attitude }\end{array}$ & $\begin{array}{l}3 \mathrm{~W}, 1 \mathrm{C}, 3 \mathrm{~A}, 3 \mathrm{l} \\
2 \operatorname{lnt}(6)\end{array}$ & 12 \\
\hline & $\begin{array}{l}\text { Impact on others (individuals, } \\
\text { groups and society) }\end{array}$ & $\begin{array}{l}3 \mathrm{~W}, 1 \mathrm{C}, 3 \mathrm{I}, 2 \mathrm{~A}, \\
1 \operatorname{lnt}(10)\end{array}$ & 10 \\
\hline & Work as enrichment of identity & $3 \mathrm{~W}, 2 \mathrm{I}, 1 \mathrm{~A}, 2 \mathrm{Int}(8)$ & 8 \\
\hline & Development visions & $2 \mathrm{~W}, 1 \mathrm{C}, 1 \mathrm{~A}, 2 \operatorname{lnt}(6)$ & 6 \\
\hline $\begin{array}{l}\text { Total positive } \\
\text { self-descriptions }\end{array}$ & - & - & 36 \\
\hline
\end{tabular}

I22, for example, views her leadership potential as being aware and committed, and a: 'deliverer of high quality'. Whilst W5 mentions her qualities in terms of being: 'forthright, effective and diplomatic'. Women define themselves in terms of their personal values, such as honesty (I18), their practical skills (e.g. 'being hands-on', I18) and their communication skills (e.g. as 'being empathetic', W5, W14).

Altogether, seven women see their identity as dynamic, highlighting how they have developed from past to present (change in leadership styles, e.g. W6, W14) or regarding emotional reactions to (repeated) experiences (e.g. W14, M8, M23). Altogether, five women describe their selfconsciousness as a core dimension of their identity and of who they are. Self-reflection is a core method used to effect self-consciousness and self-awareness as part of the identity. I9 speaks abouts 'being emotionally aware' as an important aspect of her identity, whilst W24 refers to 'gender awareness' as identity building, and M28 makes mention of a strong 'self-awareness'.

Four women emphasise their professional career identity in the context of work-family balance and how women leaders develop, maintain and live their 'professional career identity', whilst having children, a family and a career (e.g. W14). One women leader (W5) describes herself as having a career because of the fact of her position as an HEI manager and speech writer. Her career is based on her ability as a womannot on her having 'an agenda of my own' - and on the fact that her career is based on serving the interests of the university's vice chancellor.

Women leaders are highly self-related, defining themselves in terms of individual potential and qualities, rather than on interpersonal, group, organisational or societal impacts. Selfdefinitions are connected to many positive self-descriptions, such as the women leaders' excitement and positive life attitude (12 statements); their positive impact on others at individual, group and societal levels (10 statements); the view to see work as an enrichment experience (8 statements); and finally, their visions regarding their leadership developments (6 statements).

In terms of identity, women leaders focus on themselves and on their personal development, which they see as exciting and positive. They value their impact on others; however, the self is central to the leaders and their leadership. They focus primarily on developing their personal mission, rather than developing others. They hardly refer to their belonging to their reference group of 'women leaders', but rather seem to be highly self-reliant, without following a networking, belonging or cooperation approach.

\section{Boundaries}

Women leaders define their boundaries in terms of different boundary markers (see Table 6). Generally, they are very aware of their boundaries, which they describe as: (1) diversity factors - in terms of religion, spirituality, race, gender and class (41 statements); thoughts and flexibility (39 statements); (2) personal boundaries - in terms of their health, balance of self and others, thoughts and flexibility; (3) space - in terms of physical, psychological and mental space (18 statements); (4) time boundaries - in terms of personal, family and work time (research and connecting) boundaries, as well as flexible work time boundaries (13 statements); (5) emotional boundaries (13 statements); (6) transpersonal boundaries - in the sense of overcoming their own limitations and boundaries (12 statements); and, finally, (7) professional boundaries - in terms of defining the professional field and academic versus management boundaries (7 statements).

For example, refering to cultural and gender-related boundary experiences:

'You can see that the men share a camaraderie that the women don't. I think there's still this whole battle that women are battling alone; a battle of not falling into the trap of allowing patriarchy to take place in relations, yet there are some who believe that it's actually ok. Therefore, depending on your cultural background as well, you've got this kind of dissonance amongst women that affects their leadership, and the cultural aspect plays a far bigger role in women and the way they relate to men than it does with men. Really, that's been my experience. It's quite a difficult terrain (that) women have to navigate.' [W5]

Cultural background and gender play a major role in how leaders define boundaries and existing differences between male and female leaders and can be attributed to historic and collective experiences. The differences of boundary experiences, in relation to cultural background, are extremely surprising, because W5 expected the boundaries to be similar for women leaders across cultures; however, they are strongly influenced by cultural upbringing.

Women also experience personal, self-made and social boundaries, which lead them to 'not to claim ideas' (e.g. M8), or they experience health-related boundaries and physical, psychological or mental limits (e.g. W6, W10). Several boundary experiences are connected with expressions of space, be it office space or other spaces. W15 highlights: 'I need some private space, my space' (W15), and W2 emphasises: 'the importance of safe space', whilst W7 requests: 'women space' and W5/W16 talk about the exclusiveness of 'boys' club space', which excludes women leaders. More boundaries are experienced because of time, 
TABLE 6: Boundaries of women leaders

\begin{tabular}{|c|c|c|c|}
\hline Boundaries & Theme & Interview numbers & Total number \\
\hline \multirow{5}{*}{$\begin{array}{l}\text { Diversity-related } \\
\text { boundaries }\end{array}$} & Religion and spiritual belief as a boundary & B12, B29, C8, C23, C28, 19, I17, I18, I22, W2, W6, W7, W10, W14, W16, W26 & 16 \\
\hline & Racial boundaries & $\mathrm{C} 8, \mathrm{C} 13, \mathrm{C} 19, \mathrm{C} 23, \mathrm{C} 21,19,122, \mathrm{~W} 5, \mathrm{~W} 10, \mathrm{~W} 13$ & 10 \\
\hline & Gender - being a woman in a man's world & B29, 19, I17, I18, I22, C13, C23, C19, W7, W14, W16, W17, W5, W11 & 14 \\
\hline & Class & $\mathrm{C} 23$ & 1 \\
\hline & Total & - & 41 \\
\hline \multirow[t]{6}{*}{ Personal boundaries } & Health-related boundaries & I17, B21, C19, C23, W6, W10, W15, W16 & 8 \\
\hline & Thought boundaries (think before speaking) & C28, W7, W16, W17, W6 & 5 \\
\hline & Be flexible (and manoeuvre if necessary) & B12, B29, 122, C18, C28, C19, W7, W10, W11, W14, W16, W17, W20 & 10 \\
\hline & Put foot down & C19 & 1 \\
\hline & Do not claim ideas & $\mathrm{C} 8$ & 1 \\
\hline & Total & - & 39 \\
\hline \multirow[t]{9}{*}{ Space boundaries } & Office space & $\mathrm{C} 12, \mathrm{C} 8, \mathrm{C} 13, \mathrm{~W} 10$ & 5 \\
\hline & Life space & B21, C8 & 2 \\
\hline & Conscious space & B29 & 1 \\
\hline & My space & W15 & 1 \\
\hline & Safe space & W2, W14 & 2 \\
\hline & Only women's space & W7 & 1 \\
\hline & Boys' club space & W5, W16 & 2 \\
\hline & Women miss exposure in work space & B29, W17, W20 & 3 \\
\hline & Total & - & 18 \\
\hline \multirow[t]{6}{*}{ Time boundaries } & Personal time & C13, C19, C23, W15, W16 & 5 \\
\hline & Family time & C19 & 1 \\
\hline & Research time & W16 & 1 \\
\hline & Time to connect with others at work & $\mathrm{B} 12, \mathrm{C} 8$ & 2 \\
\hline & Flexible work time & $\mathrm{B} 12, \mathrm{I22}, \mathrm{C} 8, \mathrm{~W} 20$ & 4 \\
\hline & Total & - & 13 \\
\hline \multirow[t]{4}{*}{ Emotional boundaries } & Happiness & W10 & 1 \\
\hline & Grief & 122 & 1 \\
\hline & Anger & $\mathrm{C} 8, \mathrm{C} 23,117,19,122, \mathrm{~W} 14, \mathrm{~W} 10, \mathrm{~W} 16, \mathrm{~W} 17$ & 9 \\
\hline & Total & - & 13 \\
\hline \multirow{3}{*}{$\begin{array}{l}\text { Transpersonal boundaries } \\
\text { (extend boundaries } \\
\text { beyond the self) }\end{array}$} & Overcome personal boundaries & B21, C28, W7, W11, W15, W26 & 6 \\
\hline & Look beyond situation & I22, C19, C23, C28, W7, W11 & 6 \\
\hline & Total & - & 12 \\
\hline \multirow[t]{3}{*}{ Professional boundaries } & Keep it professional & 19, I22, W14, W11, W16 & 5 \\
\hline & Academic versus management & C19, W11 & 2 \\
\hline & Total & - & 7 \\
\hline Total boundary & - & - & 143 \\
\hline
\end{tabular}

which are connected to certain topics (e.g. research time) or to relationships or contexts (e.g. family time).

Another very interesting aspect is the reference to 'emotional boundaries', such as anger, grief, fear, passion and happiness. Thereby, positively valued emotions seem to expand boundaries and open up spaces, whilst negatively experienced emotions seem to support women leaders in experiencing their boundaries and might even be used as a signal to emphasise limits and demarcations. One reflected on her anger as follows:

'In earlier years, I didn't have a PhD, I didn't have the status, and I was a woman. And there were a few times when I felt very angry and very badly treated, by men mostly'. [W16]

The experiences of anger lead to reflections on personal and social boundaries and to negative, limiting experiences with male colleagues. This experience, however, motivated her
(W16) to move ahead with her career. Indeed, several women leaders highlight that they use the experience of boundaries to transcend, develop and move beyond the situation.

Finally, some women refer to professional boundaries, which they will point out, for example, when their colleagues overstep their boundaries and when they want to protect themselves. 19, comments:

'And I tell them that they must just keep it professional.'

when her colleagues infringe on her boundaries or disrespect her. Only two women leaders (C19, W11) see clear boundaries between academics and administrators in HEIs and they feel that these need to be decreased. Women leaders experience boundaries through their social contexts (e.g. male colleagues) and variously identify this as protection or limitations and as indicators as to where to develop further. Boundaries are experienced as physical, 
TABLE 7: (De-)authorisation of women leaders.

\begin{tabular}{|c|c|c|c|}
\hline Authority & Theme & Interview numbers & Total number \\
\hline \multirow{7}{*}{$\begin{array}{l}\text { Strategies to } \\
\text { deal with } \\
\text { authority }\end{array}$} & $\begin{array}{l}\text { Religion or God tells me how } \\
\text { to deal with authority }\end{array}$ & $\begin{array}{l}\text { B12, I18, 122, C23, } \\
\text { C28, W7, W10, W17 }\end{array}$ & 8 \\
\hline & Lead from the back & C8, W5 & 2 \\
\hline & Step out of victimhood & W5, C13, B29, 19, 122 & 5 \\
\hline & Step back and withdraw & $117,122, \mathrm{C} 8$ & 3 \\
\hline & $\begin{array}{l}\text { Step into your potential or } \\
\text { ownership }\end{array}$ & C19, W11, 122, C28 & 4 \\
\hline & Authority through knowledge & $\mathrm{C} 13$ & \\
\hline & Total & - & 23 \\
\hline \multirow[t]{6}{*}{ No authority } & Because of religion & 19 & 1 \\
\hline & Because of (younger) age & $\mathrm{B} 12, \mathrm{I18}, \mathrm{I22}, \mathrm{C} 8, \mathrm{C} 19$ & 5 \\
\hline & Because of cultural background & $19, \mathrm{I} 18, \mathrm{C} 8, \mathrm{C} 23$ & 4 \\
\hline & $\begin{array}{l}\text { Because of gender } \\
\text { (being a woman) }\end{array}$ & $\mathrm{B} 12, \mathrm{C} 8, \mathrm{C} 13, \mathrm{C} 23$ & 4 \\
\hline & $\begin{array}{l}\text { Because of race and gender } \\
\text { combined }\end{array}$ & $C 23,19,118,117,122$ & 5 \\
\hline & Total & - & 19 \\
\hline \multirow{4}{*}{$\begin{array}{l}\text { Impact on } \\
\text { authority }\end{array}$} & Men have authority & $\mathrm{C} 13, \mathrm{C} 23$ & 2 \\
\hline & $\begin{array}{l}\text { System chaotizises women's } \\
\text { authority }\end{array}$ & B12 & 1 \\
\hline & Women's voices stay unheard & B29, I17, I18, C13 & 4 \\
\hline & Total & - & 7 \\
\hline Total authority & - & - & 49 \\
\hline
\end{tabular}

psychological, mental, emotional, professional, contextual, social, gender and racial/cultural boundaries.

\section{Authority}

Women leaders are concerned with authority, emphasising strategies to deal with it, such as religion, 'leading from the back', overcoming victimhood, withdrawing, 'stepping into potential', ownership and knowledge (23 statements) (see Table 7). C27 points out the importance of women leaders to be active and to take ownership:

\begin{abstract}
'An important leadership concept is the ability to step into your power - take ownership and step into your power. Very often I've seen, particularly as women, and this is a gendered comment I am making now, we intuit things, we understand, we know what's happening, we know what should be done, but we are not able to step into our power and ensure that it happens.'
\end{abstract}

Altogether, 19 statements refer to the participants feeling that they do not have authority because of religion, age, cultural background, gender or both, race and gender. I9 states:

'They started to investigate my management style last year and I had to go through the entire year, which was difficult, because there was uncertainty, and my authority was undermined, which lead to me being investigated as though I was doing something untoward. The negatives were actually trumped up in a report, all because I am a short, dark woman.'

Finally, seven statements refer to authority in general, highlighting that men have authority, the system has authority and that women's voices are not heard within the male-dominated authoritarian system.

An Indian leader speaks critically about women leaders gaining more authority 'in the near future' in HEIs. She points out that stepping back is an adequate intervention when authority is rejected. She highlights (I17):
'I simply stepped back from that particular role that I was playing. I think it is also important to decide which strategy to adopt when dealing with authority. I don't think that's a space where we are going to win the gender battle any time soon. Therefore, I would rather redirect my energies and when the time is right, go back to that space in HEIs.'

In summary, the data show that women leaders focus on strategies to deal with authority and largely feel that they do not have, or are not being given, authority. They see authority being placed outside of themselves in men and the system. This shows that they do not locate authority within themselves and this is what is holding them back and inhibiting them from taking action and ownership, which impacts on them visibly in the workplace.

\section{Role}

The women leaders defined their role in terms of their work roles (56 statements) (interactor or collaborator, carer, nurturer, achiever, professional and strategic advisor), and their workfamily roles (32 statements) (negotiating complexities of being a mother to their children, a mother at work, a mother and a professional with a high work load and a daughter) (see Table 8). They also defined their role in terms of their (life's) purpose (23 statements) (make things work, make people feel good, contribute to the overall good and be servant leaders). They see themselves in a social role (18 statements), caring for students and 'helping the underprivileged' (7 statements) (the latter only mentioned by black leaders, Indian leaders and coloured leaders). They generally made references to women leaders' need for flexibility to adjust to their roles contextually and situationally. They confirmed that they play a 'critical role' within the system. Finally, two black women highlighted that women should find an adequate gender role (2 statements) and should 'not to act as men'.

A coloured leader (C28) highlights that she had to adjust her expectations about her contribution and her role during fulfilling her work duties:

'I actually started thejob being quite upbeat about the contribution I could make, but more and more I found that the contribution I make is much further from the ideal because I am more of a bureaucrat than an enabler. I tend to churn out reports and provide information, conduct training and the like; I felt I would play much more of a strategic advisory role. So, it is a challenge.'

This woman leader is disappointed that she fulfils duties in her leadership role, as opposed to enabling people in her job. She experiences a huge gap between her ideal and the reality at work. She expected more of an advisory role; however, the environment does not allow that and only provides her with an executive role. Black women, in particular, relate to their role as social supporters of students and the 'underprivileged'. B21 comments:

'Most of the students that I work with are underprivileged. What makes my life worth it is when I actually see that underprivileged children, who come through my classroom for the first time, without good knowledge, blossom, and at the end of the year, they get a distinction, finish their programmes and succeed. I can look back and know that I made a difference in that person's life.' 
TABLE 8: Role of women leaders.

\begin{tabular}{|c|c|c|c|}
\hline Role & Theme & Interview numbers & Total number \\
\hline \multirow[t]{7}{*}{ Role at work } & Interactor or collaborator & B29, I17, C13, C23, C28, C19, W7, W15, W16, W17, W5, W6, W11, W2 & 14 \\
\hline & Carer & I17, B12, B21, B29, C13, C23, W7, W14, W15, W17, W6, W10, W11 & 13 \\
\hline & Nurturer & W16, W5, 19, B12, B21, C28 & 6 \\
\hline & Achiever & C23, B12, I17, I22, W7, W14, W16, W11 & 8 \\
\hline & Professional & $\mathrm{B} 21,19,117,122, \mathrm{C} 8, \mathrm{C} 13, \mathrm{C} 23, \mathrm{C} 28, \mathrm{C} 19, \mathrm{~W} 15, \mathrm{~W} 16$ & 11 \\
\hline & Strategic advisor & C28, W15, W17, W5 & 4 \\
\hline & Total & - & 56 \\
\hline \multirow[t]{6}{*}{ Work-family role } & Be a mother to children & W14, W20, W26, I22, B12, B29, C8, C13, C19 & 9 \\
\hline & Be a mother as a professional & $117,122, \mathrm{C} 13, \mathrm{C} 23$ & 4 \\
\hline & Be a mother and a professional & B12, B21, I22, C8, C19, W7, W14, W16, W5, W20 & 10 \\
\hline & Be a daughter & $\mathrm{B} 29, \mathrm{C} 23, \mathrm{C} 19, \mathrm{~W} 10, \mathrm{~W} 20, \mathrm{~W} 2$ & 6 \\
\hline & Reject extra responsibilities at work because of family role & B21, I22, C19 & 3 \\
\hline & Total & - & 32 \\
\hline \multirow[t]{4}{*}{ Role in terms of purpose } & Make things work & B29, B21, B12, W7, W17, 19, I17, I18, I22, C13, C23, C28, C19 & 13 \\
\hline & Contribute to overall good & $122, \mathrm{C} 19, \mathrm{C} 28$ & 3 \\
\hline & Be a servant leader & B3, C28 & 2 \\
\hline & Total & - & 23 \\
\hline \multirow[t]{3}{*}{ Social role } & Caring for students in general & B12, B12, 19, I17, C8, C13, W17, W15, W11, W7 & 10 \\
\hline & Helping underprivileged students (gender and race) & $\mathrm{B} 21,19,117, \mathrm{C} 8, \mathrm{C} 13, \mathrm{C} 23, \mathrm{C} 29, \mathrm{C} 19$ & 8 \\
\hline & Total & - & 18 \\
\hline \multirow[t]{3}{*}{ Role attitude } & Be flexible about which role to choose & $\mathrm{C} 8, \mathrm{~W} 14,122, \mathrm{~B} 21, \mathrm{~B} 29$ & 5 \\
\hline & Play a critical role & $19, \mathrm{C} 8$ & 2 \\
\hline & Total & - & 7 \\
\hline \multirow[t]{2}{*}{ Gender role } & Be a woman, do not act as a man & B12, B29 & 2 \\
\hline & Total & - & 2 \\
\hline Total role & - & - & 139 \\
\hline
\end{tabular}

TABLE 9: Tasks of women leaders.

\begin{tabular}{|c|c|c|}
\hline Role: Theme & Interview numbers & Total number \\
\hline Manage conflict & $\begin{array}{l}\text { B29, 19, I17, C13, C19, C28, W2, } \\
\text { W3, W5, W6, W7, W10, W11, } \\
\text { W14, W15, W17, W20, W26 }\end{array}$ & 18 \\
\hline Find solutions & $\begin{array}{l}\text { B29, I9, I17, C8, W2, W6, W7, } \\
\text { W10, W11, W17 }\end{array}$ & 10 \\
\hline Make a difference & $B 12,19,117,122, W 3, W 5, W 7, W 14$ & 8 \\
\hline $\begin{array}{l}\text { Produce or perform } \\
\text { (within deadlines) }\end{array}$ & $\begin{array}{l}\text { B12, C23, 19, 122, W7, } \\
\text { W20, W26 }\end{array}$ & 7 \\
\hline Follow procedures & B29, C28, W5, W6, W20, W26 & 6 \\
\hline Release policies or info & B29, C13, C19, C28, W5, W11 & 6 \\
\hline Research and teach & W5, W7, C13, W15, W16, W20 & 6 \\
\hline Report or write reports & $\mathrm{B} 12, \mathrm{C} 19, \mathrm{C} 28, \mathrm{~W} 5, \mathrm{~W} 16$ & 5 \\
\hline Develop the system & B12, W7, W11, I17 & 4 \\
\hline Manage (order) & B12, W2, W11 & 3 \\
\hline Fulfil a God-given/religious task & B12, W26 & 2 \\
\hline Total task & - & 75 \\
\hline
\end{tabular}

B21 highlights her role as a supervisor and lecturer in 'making a difference' pertaining to underprivileged students, which makes her work role a meaningful one.

I9 emphasises the 'critical role' of women leaders across the world:

'He in this country has a long way to go. There are a lot of brilliant women, who have an important role to play, and I think there should be recognition for that, and not the feminine aspect of what you have to offer. I think we have a critical role to play in the world, yet sadly, it is lacking.'

Although the critical role seems to still lack in this space, this woman pleads for perseverance on the part of women leaders. However, two black women highlight what women should not do (B12):

'Please try and avoid acting like men, and secondly, avoid acting like you know everything, because you don't know everything. Learn to treat people well. I believe that as women we can make a big difference in terms of production and what we achieve, if we treat people well.'

In summary, women leaders fulfil different roles and they have to be flexible. They are seen as 'motherly' (caring and nurturing) and they need to balance work and family roles. They also take on social roles, such as to look after others. Women leaders need to find a balance, act as women, know what their boundaries and identities are and must assume authority.

\section{Task}

The primary task in the job as women leaders in HEIs is to manage conflict (18 statements) and find solutions (10 statements) (see Table 9). Women see their task in 'making a difference' (8 statements) and performing (7 statements). Following procedures ( 6 statements) and releasing policies (6 statements) are also important. Women leaders see research and teaching (6 statements), writing reports (5 statements), developing the system (4 statements) and managing work (3 statements) as a God-given task (2 statements).

C13 refers to conflict management and multiple other tasks:

'You've got to do your teaching properly and publish and research, and you've got to do institutional work for the chair. 
Sometimes you find you are pulled in different directions, and you also have different demands placed on you, therefore, you need to negotiate conflictual demands. I suppose conflict is very subtle in the academic context. You get your usual issues such as people maybe arguing about workload, which are things you can see and talk about, but then there can be other conflict - one main task is to resolve it.'

Four women refer to the task to develop the system. W7 emphasises, for example:

'So we're going to have to work out a system that is fair and transparent for all and develop the system.'

The tasks of HEI leaders are diverse; however, conflict is one major task women leaders have to deal with. That might be a reason why two women leaders highlight the importance of God and religious tasks that should contextualise work tasks. W27, who is a Buddhist, explains that work and belief are connected: 'I started realising the significance between what I do as an academic, living in the present moment and being mindful. I see them as akin'.

To summarise, the tasks of women leaders are experienced as multifold. They seem to be mainly related to communication and the de-escalation of conflict. These tasks constitute a large portion of the day, more than teaching, research, supervision and administrative tasks. It might be that conflict management tasks are underrated; however, in HEI, they play out on manifest and latent levels and define a major part of the work task (Cilliers \& Koortzen, 2005).

\section{Discussion}

This study shows clearly the struggle of women leaders in HEIs in South Africa. It provides an insight into the complex (un-)conscious dynamics and patterns, which are strongly impacted on by deep anxieties (Armstrong, 2005), fears and psychological pain, which the system defends against (Sievers, 2009), whilst women leaders act as containers of such. Women leaders are very aware of the dynamics they are in and they try their best to integrate positive and negative aspects to cater for object and human relations to contain the fear (Cytrybaum \& Noumair, 2004). However, how conscious women leaders are about their role as containers of anxiety of the system remains an open question. Within HEI, women leaders experience high levels of conflict as subsystems mirror one another (as previously described by Naik, 2014; Nossal, 2007; Shongwe, 2014), influencing leadership, role formation, identity boundaries and authority as unconscious patterns of ego defences to create increased security (as highlighted by Koortzen \& Oosthuizen, 2012).

Conflicts make up a huge part of work tasks and seem to be important, not merely a basic component, as described by Cilliers and Koortzen (2005). That might lead to the assumption that HEI systems are riddled by anxiety, which manifests through diverse conflict experiences. It might be assumed from a systems psychodynamic perspective that women leaders are only partly conscious of the underlying anxiety created from conflicts and their defensive mechanisms towards these mechanisms (Van Tonder, 2012).

The study shows that women leaders partly split from other women leaders by using diversity markers, such as race, age, language or work division to make the systems appear to be smaller and therefore safer (Koortzen \& Oosthuizen, 2012). They therefore refer to conflicts in terms of gender inequalities (Ragadu, 2008; Surajlall, 2012) on individual, group, organisational and societal levels. They, at the same time, pair with 'powerful others' (Koortzen \& Oosthuizen, 2012), such as male leaders or parental figures (e.g. mothers) to contain and thereby overcome anxiety. Women leaders hold a strong sense of 'who they are'; however, they seem to lack identification with the systems' values (Cilliers \& Koortzen, 2005; Naik, 2014) and rather experience a 'split' from other women leaders than a 'pairing', which can be interpreted as a strong defence mechanism to deal with anxiety on a conscious level. They, therefore, do not identify strongly with the HEI system and hardly feel any sense of belonging to the system, but rather align themselves with their families, which are smaller systemic units and more suitable to contain anxiety. This obviously affects women leaders' self-identity and self-authority in terms of their own sense of potential, ambition, achievement and self-worth at work, as previously described by Naik (2014).

In terms of roles, women leaders focus on caring, nurturing and interacting; roles which can be interpreted as defence mechanisms in response to unconscious anxiety leading to regression of leadership roles in terms of 'motherly family role attributes', rather than professional role attributes, which are less frequently mentioned (achieving, being professional, strategic advisor). These findings are not coincidental and the focus on caring or nurturing roles, managing day-to-day tasks and, lastly, strategic positions (Bygren \& Gahler, 2012; Koortzen \& Cilliers, 2007) might be a defence against evolving conscious anxiety. Women leaders refer to the concept of the 'mother' in different ways, to feel secure (Bion, 1961) and to manage anxiety by referring to the role of a (imaginative) caring parental figure (Steyn \& Cilliers, 2016). On the one hand, it provides women leaders with an alternative and therefore the perception of a small and safe space within which to take up the leadership role.

On the other hand, it does create confusion in the system. Some members, it would seem, would rather deal with the perceived mother role (professionalised motherhood) than with female leaders. This is supported by the statements in support of, particularly, 'underprivileged' students. The categorisation of HEIs into privileged and unprivileged, by the women leaders, creates spaces of 'one-ness and we-ness' and this is particularly prevalent amongst the black women leaders, who are regarded previously as disadvantaged and underprivileged. Furthermore, the underprivileged students again help these women leaders to manage anxieties and create the feeling of authority and an authoritarian role in connection to students rather than towards colleagues, other 
leaders (relational authority) or the system (structural authority). Women leaders hardly refer to their normative roles, but are rather engaged with their existential (past experiences, values and preferences) and phenomenal roles and tasks (projections), which is unconsciously driven by team behaviour and leads to underperformance and deepened anxieties (see Cilliers \& Koortzen, 2005), which are again related to high-conflict experiences.

Professional identity is not the focus of women leaders connected to the low levels of experienced and perceived authority at work. The role of the mother, therefore, seems to provide them with higher levels of feelings of authority, control and influence, connecting them to their own parental figures requiring them to take up authority by 'leading from behind', 'stepping out of victimhood' and by 'stepping back'. This shows that women leaders rather prefer the 'flight response' to deal with anxieties than to 'fight' (Steyn \& Cilliers, 2016). They thereby step out of the systems' boundaries, instead of drawing new individual boundaries, by creating a safe space within the system and taking up ownership and authority within their professional roles. This might also show that women leaders are overwhelmed by the systems' inherent anxiety, which they can only contain to a certain degree. Particularly because they experience their professional roles as being authorised by others and they are hardly supported by their teams (as in Koortzen \& Cilliers, 2007).

Boundaries determine what belongs to the system and what does not (Cilliers \& Koortzen, 2005; Geldenhuys, 2012). It seems as if women leaders' boundaries are blurred and unclear, obviously resulting in role confusion (mothers or leaders). Role confusion could be exacerbated, if women leaders acknowledge that they (un-)consciously act in their role as mothers as containers for the system's inherent anxiety (Koortzen \& Cilliers, 2007; Naik, 2014; Stapley, 2006).

Women leaders feel de-authorised because of religious, agerelated, cultural, gender, racial and intersectional aspects. In addition, they experience that belonging to certain collective identities (creation of we-ness), makes them lose authority within the professional field and they feel that they are 'not being heard', even if they try to claim authority. This, on the one hand, leads to partly 'pairing with male attitudes' (as criticised by other women leaders), to fighting against the 'male enemy' or against other women leaders (e.g. those who are a different racial background), the creation of one-ness or we-ness (amongst, for instance, the underprivileged or the entire group of women leaders) and me-ness and, therefore, the detaching from group associations and the focus on the self rather than on group belonging. Whilst women struggle with different, opposing and conflictual ways of containing anxieties within the system, men remain in authority and (seem to) deal with tasks.

Further, research suggests that the low authority felt by women may be because of men still being experienced as the 'authority in the house/at home', which may lead to unconscious ideas of males being authorities per se
(Van Eeden, 2010). Bygren and Gahler (2012) suggest that women are treated differently from men in that the underlying dynamics see women's main responsibilities as being mothers, disregarding the context, again referring to containing anxieties through using parental figures (Steyn \& Cilliers, 2016).

Koortzen and Cilliers (2007) note that systems may not allow women to step out of the role of nurturers and carers, as this would increase anxiety within the system. Evident in women leaders' experiences of the difficulty of taking up authority, as legitimised by the system (Beck \& Visholm, 2014), when informal authority and unconscious dynamics are at play concerning who has authority and who has no authority (Beck \& Visholm, 2014; Cilliers \& Koortzen, 2005). The findings show unconscious dynamics affect women leaders' self-identity and authority regarding their own sense of potential, ambition, achievement and self-worth (Koortzen \& Cilliers 2007; Naik, 2014). Women leaders are less likely to exert workplace authority (Bygren \& Gahler, 2012), as this study emphasises, women leaders' orientation to manage conflict and tasks are geared more towards managerial rather than academic-related tasks.

Very few women aim at developing the system (as shown in the data). They are, instead, guided by the system's duties (follow procedures, report and release policies), as opposed to taking ownership of the system and developing it. Kaiser and Wallace (2016) note a double-bind situation in which women, who manage in this way, are viewed by the system as reliable executors and placed in familiar assignments, but are not considered for leadership roles because of a lack of perceived strategic impact. This prevents them from taking full authority. Playing a 'minor' role, in terms of tasks, might be evidence of the system's dynamics, keeping women leaders and the system off-task (Cilliers \& Koortzen, 2005), as it grapples to contain anxiety.

With the system's confusion of boundaries and roles, women find limited time or space to concentrate on evident tasks, such as research and teaching. They find leadership in HEIs a stifling space to be in, as expressed in the boundary statements, specifically references to 'limited space', a 'boy's club space', need for an 'women-only space', 'safe space', 'my space' and even 'life space', and also the references to group reactions in terms of pairing up of individuals, one-ness or we-ness and me-ness (Steyn \& Cilliers, 2016). They highlight their need to overcome their (personal) boundaries to evolve and develop (to overcome me-ness), patently not taking the system dynamics into account. In a possible attempt to break free from the assigned (parental) roles, a few women highlight that it is time to 'take ownership', through increasing knowledge. Others state that 'women should not try to act as men' in their leadership role - an idea in which the indirect 'pairing up' with men as leaders is strongly criticised. Furthermore, male leadership and pairing of women and male leaders seem to create a 'fight' reaction against an (imaginary) enemy (Steyn \& Cilliers, 2016). Additionally, 
'acting as a man' is not decoded for what it is: a common defence mechanism to self-authorisation (Naik, 2014).

As women leaders consciously aim to keep professional boundaries, by 'not having their emotions interfere', this research indicates a split between women leaders in academic and management positions, which is set through clear boundaries to create smaller and safer spaces (Cilliers \& Koortzen, 2005).

\section{Conclusion}

The purpose of this study was to explore women leaders' experiences in HEIs from a systems psychodynamic perspective through the framework of the CIBART model. Using this model adds to previous studies and assisted in illustrating that women leaders are highly involved in the unconscious dynamics at play within their HEIs on a conscious and unconscious level. The perspective of systems psychodynamics reveals new insights into the complexity of conscious and unconscious dynamics taking place around the issues women leadership when applying the CIBART model. Women leaders find themselves in constant revaluation and reconstruction, highlighting diversity aspects, particularly gender and race, but also aspects such as mother tongue, position, role and age as highly influential. A huge problem is the experience of de-authorisation and role confusion in women leaders (professional mothers), which impacts negatively on their self-image, empowerment and ownership and serves the self-interest of the system to contain anxieties on an unconscious level. De-authorisation strategies and off-task behaviour further come into play to contain anxieties.

Referring to the overview of five possible group behaviour reactions as suggested by Steyn and Cilliers (2016), it can be highlighted that this study shows that relating to imagined parental figures, pairing up with individuals and the creation of one-ness and we-ness across different diversity markers are used to contain anxiety, fear and psychological pain. To a lesser extent, women leaders also practice the flight and fight response and the me-ness reaction. We may then conclude that HEIs are riddled by anxiety and fear, which, to a large extent, is caused by societal and organisational changes and inadequate conscious strategies to deal with uncertainties, pain and fear, so that women leaders end up becoming unconscious containers of fear rather than leaders of organisations.

\section{Recommendations for future research and practice}

Future research investigating women leaders through the CIBART model should be considered. Thereby, different qualitative and quantitative methodological approaches should be used, for example, in-depth interviews or even autoethnographical or autobiographical experiences and reflexivity. In future studies, the underlying fear and anxieties of women leaders should be explored in more depth, as well as the systemic and psychological causes and how they relate to the different defence mechanisms and behavioural reactions to manage and/or contain anxieties.

It also needs to be explored how defence mechanisms and the experience of conflicts are related and which diversity markers play a role and to which degree, from a systems psychodynamics perspective. The dynamics around professional roles and the roles as mothers, of women leaders, within organisations need to be studied in-depth. Future research also needs to address and explore women leader's roles and how they manage their transformational boundaries as described by Steyn and Cilliers (2016). Finally, practical and applied research studies are needed that evaluate women leadership training and their impact to deal with the dynamics and the related anxiety within systems.

On a practical level, leadership training should acknowledge system psychodynamics in organisations and create awareness around the topics of containment and anxieties within organisations. Leadership training should use applied systems psychodynamic interventions to create increased awareness and mindfulness in women leaders and establish ways to successfully address and contain anxieties, whilst filling up the roles of professional organisational leaders and being on-task. This leadership training should also deal with issues of roles, authorisation, ownership and professionalism by using self-reflective approaches, reflexivity training and the definition of boundaries whilst creating new ways of defining who women leaders are and what to be as (future) women leaders in authority and on-task.

\section{Acknowledgements}

We thank Higher Education Resource Services South Africa (HERS-SA) for commissioning this research project and all the women who participated.

\section{Competing interests}

The authors declare that they have no financial or personal relationship(s) that may have inappropriately influenced them in writing this article.

\section{Authors' contributions}

C-H.M. was the key researcher and collected data together with S.S. who was the project leader. Data analysis was conducted by C-H.M. C-H., L.T. and R.O. contributed to the writing of the article.

\section{References}

Alexander, L.L., LaRosa, J.H., Bader, H., Garfield, S., \& Alexander, W.J. (2014). New dimensions in women's health (6th ed.). Burlington: Jones \& Bartlett Learning.

Angervall, P., Beach, D., \& Gustafsson, J. (2015). The unacknowledged value of female academic labour power for male research careers. Higher Education Research \& Development, 34(5), 815-827. https://doi.org/10.1080/07294360.2015.1011092

Armstrong, D. (2005). Organization in the mind: Psychoanalysis, group relations and organizational consultancy. London, England: Karnac.

Babbie, E., \& Mouton, J. (2006). The practice of social research. Oxford: Oxford University. 
Baxter, J. (2012). Exploring personality traits, mindfulness and sense of coherence of women working in higher education. Feminist Research: The Encyclopedia of Applied Linguistics, 17, 107-116. https://doi.org/10.1002/9781405198431. of Applied

Beck, U.C., \& Visholm, S. (2014). Authority relations in group relations conferences and in 'real life' group relations conferences. Danish Design I 1, 14(2), 227-237.

Bion, W.R. (1961). Experiences in groups. London: Routledge.

Blackman, J.S. (2004). 101 defenses: How the mind shields itself. New York: BrunnerRoutledge.

Booysen, A.E.L., \& Nkomo, S.M. (2010). Gender role stereotypes and requisite management characteristics: The case of South Africa. Gender in Management: An International Journal, 25(4), 285-300. https://doi.org/10.1108/175424110 11048164

Boyd, R. (2016). The search for lasting peace: Critical perspectives on genderresponsive human security ( 2 nd ed.). London: Routledge.

Bygren, M., \& Gahler, M. (2012). Family formation and men's and women's attainment of workplace authority. Social Forces, 90(3), 795-816. https://doi.org/10.1093/sf/ sor008

Charmaz, K. (2011). A constructivist grounded theory analysis. In F.J. Wertz, K. Charmaz, L.M. McMullen, R. Josselson, R. Anderson, \& E. McSpadden (Eds.), Five ways of doing qualitative analysis (pp. 165-204). New York: The Guilford Press.

Cilliers, F., Greyvenstein, H., \& Africa, S. (2012). The impact of silo mentality on team identity: An organisational case study. SA Journal of Industrial Psychology, 38(2), 1-9. https://doi.org/10.4102/sajip.v38i2.993

Cilliers, F., \& Koortzen, P. (2005). Working with conflict in teams - The CIBART model. HR Future, pp. 52-53.

Cilliers, F., \& May, M. (2012). The directors' roles in containing the Robben Island diversity experience (RIDE). SA Journal of Industrial Psychology, 38(2), 1-10. https://doi.org/10.4102/sajip.v38i2.986

Cilliers, F., \& Smit, B. (2006). A systems psychodynamic interpretation of South African diversity dynamics: A comparative study. South African Journal of Labour Relations, 30(2), 5-18.

Cilliers, F., \& Terblanche, L. (2010). The systems psychodynamic leadership coaching experiences of nursing managers: Original research. Health SA Gesondheid, 15(1), a457. https://doi.org/10.4102/hsag.v15i1.457

Clarke, S., \& Hoggett, P. (2009). Researching beneath the surface: Psycho-social research methods in practice. London: Karnac.

Coovadia, H., Jewkes, R., Barron, P., Sanders, D., \& McIntyre, D. (2009). The health and health system of South Africa: Historical roots of current public health challenges. The Lancet, 374(9692), 817-834. https://doi.org/10.1016/S0140-6736(09)60951-X

Creswell, J.W. (2013). Qualitative inquiry \& research: Choosing among five approaches (3rd ed.). London: Sage.

Cytrynbaum, S., \& Noumair, A. (2004). Group dynamics, organizational irrationality, and social complexity: Group relations reader 3. Jupiter, FL: A.K. Rice Institute.

De Klerk, J.J., \& Africa, S. (2012). Improvement interventions: To what extent are they manifestations of social defences? South African Journal of Industrial Psychology 38(2), 1-10. https://doi.org/10.4102/sajip.v38i2.999

Dilthey, W. (2002 [1910]). The formation of the historical world in the human sciences. In Wilhelm Dilthey selected works. Volume IV. (pp. 235-261). Princeton, NJ: Princeton University.

Du Plessis, Y., \& Barkhuizen, N. (2012). Career path barriers experienced by women engineers. Paper presented at the 12 th European Academy of Management engineers. Paper presented at the 12th European A
Conference, 06-08 June 2012. Rotterdam: Netherlands.

Eloquin, X. (2016). Systems-psychodynamics in schools: A framework for EPs undertaking organisational consultancy. Educational Psychology in Practice, 32(2), 163-179. https://doi.org/10.1080/02667363.2016.1139545

Englander, M. (2016). The phenomenological method in qualitative psychology and psychiatry International Journal of Qualitative Studies on Health and Well-being, 11, 30682. https://doi.org/10.3402/qhw.v11.30682

Enke, K.A.E. (2014). Identities, intentionality and institutional fit: Perceptions of senio women administrators at liberal arts colleges in Midwestern USA. Highe Education Research \& Development, 33(1), 100-113. https://doi.org/10.1080/07 294360.2013.864614

Fossey, E., Harvey, C., McDermott, F., \& Davidson, L. (2002). Understanding and evaluating qualitative research. Australian and New Zealand Journal of Psychiatry, 36, 717-732. https://doi.org/10.1046/j.1440-1614.2002.01100.x

Geldenhuys, D.J. (2012). Group-as-a-whole as a context for studying individual behaviour: A group diagnostic intervention. South African Journal of Industrial Psychology, 38(2), 1-12. https://doi.org/10.4102/sajip.v38i2.1011

Golom, F.D. (2017). Debra A. Noumair: Understanding organizational life beneath the surface. In D.B. Szabla, W.A. Pasmore, M.A. Barnes, \& A.-N. Gipson (Eds.), The surface. In D.B. Szabla, W.A. Pasmore, M.A. Barnes, \& A.-N. Gipson (Eds.), The
Palgrave handbook of organizational change thinkers (pp. 1-13). Cham, CH: Palgrave handbook of
Springer International.

Gouws, A. (2008). Obstacles for women in leadership positions: A case of South Africa. Signs: Journal of Women in Culture and Society, 34(1), 21-27. https://doi. org/10.1086/588486

Greyvenstein, H. \& Cilliers, F. (2012). Followership's experiences of organisational leadership: A systems psychodynamic perspective. South African Journal of IndustrialPsychology, 38(2), 1-10. https://doi.org/10.4102/sajip.v38i2.1001

Henning, S. (2009). Towards a system psychodynamic model of psychological wellness. Doctoral thesis. Pretoria, South Africa: University of South Africa.

International Labour Organization. (2010). Facts on women at work. Retrieved July 15, 2015, from http://www.ilo.org/gender
Jackson, D., Engstrom, E., \& Emmers-Sommer, T. (2007). Think leader, think male and female: Sex vs, seating arrangement as leadership cues. Sex Roles, 57(9-10), 713-723. https://doi.org/10.1007/s11199-007-9289-y

Janssen, O., \& Giebels, E. (2013). When and why creativity-related conflict with coworkers can hamper creative employees' individual job performance. European Journal of Work and Organizational Psychology, 22(5), 574-587. https://doi.org/ 10.1080/1359432X.2012.669524

Kaiser, B., \& Wallace, W.T. (2016). Gender bias and substantive differences in ratings of leadership behaviour: Toward a new narrative. Practice and Research, 68(1), 72-98.

Khoury, G.C., \& McNally, B. (2016). The role of the leadership style in creating conflict and tension in a higher education institution. In A.H. Normore, L.W. Long, \& M. Javidi (Eds.), Handbook of research on effective communication, leadership and conflict resolution (pp. 233-248). PA: IGI Global.

Kinnear, L. (2014). A critical analysis of the emerging models of power amongst South African women business leaders. Unpublished doctoral thesis, University of KwaZulu-Natal, Durban, South Africa.

Koortzen, P., \& Cilliers, F. (2002). The psychoanalytical approach to team development. In R.L. Lowman (Ed.), Handbook of organizational consulting psychology (pp. 260-284). San Francisco, CA: Jossey-Bass.

Koortzen, P., \& Cilliers, F. (2007). Symbolism associated with leadership: A systempsychodynamic perspective. Retrieved n.d. from http://uir.unisa.ac.za/handle/ $10500 / 18430$

Koortzen, P., \& Oosthuizen, R.M. (2012). Psychological experiences in South African society before the 2010 FIFA World Cup from the systems psychodynamic and positive psychology perspectives. SA Journal of Industrial Psychology/SA Tydskrif vir Bedryfsielkunde, 38(2), Art. \#976, 1-13. https://doi.org/10.4102/sajip.v38i2.976

Krane, V., Karlsson, B., Ness, O., \& Binder, P. (2016). They need to be recognized as a person in everyday life: Teachers' and helpers' experiences of teacher-student relationships in upper secondary school. International Journal of Qualitative Studies on Health and Well-being, 11,31634. https://doi.org/10.3402/qhw.v11. 31634

Littrell, R.F., \& Nkomo, S.M. (2005). Gender and race differences in leader behaviour preferences in South Africa. Women in Management Review: An International Journal, 20, 562-580. https://doi.org/10.1108/09649420510635204

Love, J., Hagberg, M., \& Dellve, L. (2011). Balancing extensive ambition and a context overflowing with opportunities and demands: A grounded theory on stress and recovery among highly educated working young women entering male-dominated recovery among highly educated working young women entering male-dominated occupational areas. International Journal of Qualitative St
Well-Being, 6, 5904. https://doi.org/10.3402/qhw.v6i3.5904

Mabokela, R.O., Kaluke, F., \& Mawila, N. (2004). The impact of race, gender and culture in South African higher education. Comparative Education Review, 48(8), 396-416. https://doi.org/10.1086/423359

Mayer, C.H. (2008). Managing conflict across cultures, values and identities. Münster, Germany: Waxmann

Mayer, C.H. (2011). The sense of coherence in trans-cultural management. Münster, Germany: Waxmann.

Mayer, C.H., \& Barnard, A. (2015). Balancing the scales of gender and culture in contemporary South Africa. In S. Safdar \& N. Kosakowska (Eds.), The psychology of gender through the lens of culture (pp. 327-353). New York: Springer.

Mayer, C.-H., \& Boness, C. (2011). Concepts of health and well-being in managers: An organizational study. International Journal of Qualitative Studies on Health and Well-being, 6(4), 7143. https://doi.org/10.3402/qhw.v6i4.7143

Mayer, C.H., \& Surtee, S. (2015). The leadership preferences of women leaders working in higher education. Generos, Multidisciplinary Journal of Gender Studies, 4(19), 612-636. https://doi.org/10.4471/generos.2015.49

Mayer, C.H., Surtee, S., \& Barnard, A. (2015). Women leaders in higher education: A psycho-spiritual perspective. South African Journal of Psychology, 45(1) 102-115. https://doi.org/10.1177/0081246314548869

Mayer, C.H., Surtee, S., \& Mahadevan, J. (2018). South African women leaders, transformation and diversity conflict intersections. Journal of Organizationa Change Management. To be published in 2018.

Mayer, C.H., Surtee, S., \& May, M.S. (2015). The meaningfulness of work for a diverse group of women working in higher education institutions. South African Journa of Higher Education, 29(6), 182-205.

Mayer, C.H., \& Van Zyl, L.E. (2013). Perspectives of female leaders on sense of coherence and mental health in an engineering environment. SA Journal of Industrial Psychology/SA Tydskrif vir Bedryfsielkunde, 39(2), Art. \#1097, 1-11. https://doi.org/10.4102/sajip.v39i2.1097

Mayring, P. (2014). Qualitative content analysis theoretical foundation, basic procedures and software solution. Klagenfurt, Austria: Psychopen.

Morley, L. (2013). International trends in women's leadership in higher education. In M. Stiasny \& T. Gore (Eds.), Going global: Identifying trends and drivers of international education (pp. 279-298). Bingley, UK: Emerald.

Mostert, K. (2009). The balance between work and home: The relationship between work and home demands and ill health of employed females. SA Journal of Industrial Psychology, 35(1), 1-8. https://doi.org/10.4102/sajip.v35i1.743

Myburg, H. (2009). The experience of organisational development consultants working in the systems psychodynamic stance. Retrieved n.d. from http://uir. unisa.ac.za/handle/10500/1473

Naik, B. (2014). System psychodynamics underlying the work-family interface amongst managerial women in the public sector. Retrieved n.d. from http://uir.unisa.ac.za/ handle/10500/18528 
Nossal, B. (2007). Systems psychodynamics and consulting to organisations in Australia. Retrieved n.d. from http://researchbank.rmit.edu.au/view/rmit:9775

O'Conner, P., Carvalho, T., \& White, K. (2014). The experiences of senior positional leaders in Australian, Irish and Portuguese universities: Universal or contingent? Higher Education Research \& Development, 33(1), 5-18. https://doi.org/10.1080/ 07294360.2013 .864608

Oliver, P. (2006). Purposive sampling. In The Sage dictionary of social research methods. Irvine, CA: Sage. Retrieved n.d. from http://srmo.sagepub.com/view/ the-sage-dictionary-of-social-research-methods/n162.xm

Ragadu, S.C. (2008). Transformation in higher education: Perceptions of female academics at a distance. Master thesis, University of Stellenbosch, South Africa. Retrieved n.d. from: https://core.ac.uk/download/pdf/37322649.pdf

Raheim, M., Magnussen, L.H., Sekse, R.J.T., Lunde, A., Jacosen, T., \& Blystad, A. (2016) Researcher-researched relationship in qualitative research: Shifts in positions and researcher vulnerability. International Journal of Qualitative Studies on Health and Well-being, 11, 30996. https://doi.org/10.3402/qhw.v11.30996

Ramgoolam, S. (2005). Experiences of employment equity in the coal mining industry. Unpublished master's dissertation. University of South Africa, Pretoria.

Ratner, C. (2002). Subjectivity and objectivity in qualitative methodology. Forum Qualitative Social Research, 3(3). Retrieved n.d. from http://www.qualitativeresearch.net/index.php/fqs/article/view/829/1800

Rothmann, S., \& Cilliers, F. (2007). Present challenges and some critical issues for research in industrial/organisational psychology in South Africa. South African Journal of Industrial Psychology, 33(1), 8-17. https://doi.org/10.4102/sajip. v33i1.262

Sanchen, H. (2009). Towards a system psychodynamic model of psychological wellness. Retrieved n.d. from http://uir.unisa.ac.za/handle/10500/2971

Surajlall, P. (2013). Career advancement of senior women through executive leadership development programmes. MBA dissertation, University of Pretoria, Pretoria, South Africa. Retrieved n.d. from: https://repository.up.ac.za/bitstream/ handle/2263/22838/dissertation. pdf; sequence $=1$

Shongwe, M. (2014). Systems psychodynamic experiences of professionals in acting positions in a South African organisation. Retrieved n.d. from http://uir.unisa.ac. $\mathrm{za} /$ handle/10500/14616

Sievers, B. (2009). Psychoanalytic studies of organizations: Contributions from the International Society for the Psychoanalytic Study of Organizations. London, England: Karnac.

South African Government. (1997). A programme for the transformation of higher education. Education, White Paper 3. Government Gazette, August, 15: 18207. Pretoria: Government Printers.

Stapley, L.F. (2006). Individuals, groups and organisations beneath the surface: An introduction. London: Karnac.
Steyn, M., \& Cilliers, F. (2016). The systems psychodynamic experiences of organisational transformation amongst support staff. South African Journal of Industrial Psychology, 42(1), 1-10. https://doi.org/10.4102/sajip.v42i1.1367

Streib, H. (2005). Faith development research revisited: Accounting for diversity in structure, content, and narrativity of faith. The International Journal for the Psychology of Religion, 15(2), 99-121. https://doi.org/10.1207/s15327582ijpr 1502_1

Struwig, H., \& Cilliers, F. (2012). Working with boundaries in systems psychodynamic consulting. SA Journal of Industrial Psychology, 38(2), 1-10. https://doi.org/ 10.4102/sajip.v38i2.987

Struwig, H., Cilliers, F., Africa, S., \& Greyvenstein, H. (2012). Followership's experiences of organisational leadership: A systems psychodynamic perspective. SA Journal of Industrial Psychology, 38(2), 1-10. https://doi.org/10.4102/sajip.v38i2.1001

Surtee, S., \& Hall, M. (2009). Transformation: African people in the Western Cape. Cape Town: Commissioned by the Development Policy Research Unit, University of Cape Town.

Terre Blanche, M., Durrheim, K., \& Kelly, K. (2006). First steps in qualitative data analysis. In M. Terre Blanche, K. Durrheim, \& D. Painter (Eds.), Research in practice: Applied methods for the social sciences (pp. 321-344). Cape Town: University of Cape Town

The Guardian. (2016). Retrieved n.d. from http://www.theguardian.com/commentisfree/ audio/2016/mar/19/hillary-clinton-female-leadership-feminist-podcast

Tracy, S.J. (2010). Qualitative quality: Eight 'big-tent' criteria for excellent qualitative research. Qualitative Inquiry, 16(10), 837-851. https://doi.org/10.1177/1077800 410383121

Ugwu, D.I., Orjiakor, C.T., Enwereuzor, I.K., Onyedibe, C.C., \& Ugwu, L.I. (2016). Business-life balance and wellbeing: Exploring the lived experiences of women in low-to-middle income country. International Journal of Qualitative Studies on Health and Well-being, 11, 30492. https://doi.org/10.3402/qhw.v11.30492

Van Eeden, R. (2010). Combining leadership theory with a psychodynamic perspective to explain the functioning of a management team. Journal of Psychology in Africa, 20(2), 311-319. https://doi.org/10.1080/14330237.2010.10820380

Van Tonder, V. (2012). Group-as-a-whole as a context for studying individual behaviour A group diagnostic intervention, pp. 1-12. http://doi.org/10.4102/sajip.v38i2.1011

Yin, R.K. (2009). Case study research: Design and methods (4th ed.). London: Sage.

Young, M., Koortzen, P., \& Oosthuizen, R.M. (2012). Exploring the meaning of trauma in the South African Police Service: A systems psychodynamic perspective. SA Journal of Industrial Psychology/SA Tydskrif vir Bedryfsielkunde, 38(2), Art. \#1004 1-11. https://doi.org/10.4102/sajip.v38i2.1004

Zambas, S.I., Smythe, E.A., \& Koziol-Mclain, J. (2016). The consequences of using advanced physical assessment skills in medical and surgical nursing: A hermeneutic pragmatic study. International Journal of Qualitative Studies on Health and Wellbeing, 11, 32090. https://doi.org/10.3402/qhw.v11.32090 